\title{
A revision of the genus Rhabdonotus A. Milne Edwards, 1879, with descriptions of two new species and the first zoeal stage of $R$. pictus A. Milne Edwards, 1879 (Brachyura: Eumedonidae)
}

\author{
Diana G. B. Chia and Peter K. L. Ng
}

Abstract. - The genus Rhabdonotus A. Milne Edwards, 1879 , is revised. The identity of Rhabdonotus pictus A. Milne Edwards, 1879, is clarified. A specimen from Singapore is designated as the simultaneous neotype of Rhabdonotus pictus A. Milne Edwards, 1879, and its junior synonym, Caphyra archeri Walker, 1887. Two new species, Rhabdonotus pilipes and Rhadonotus xynon, are described. A key to the three species is provided. The first zoeal stage of $R$. pictus A. Milne Edwards, 1879, is also described for the first time.

\section{Introduction}

The peculiar crab symbiotic with comatulid crinoids, Rhabdonotus pictus A. Milne Edwards, 1879, is poorly known, and the genus has been regarded as monotypic. This species has been recorded from Thailand, Singapore, China and Australia (Stevcic et al., 1988; Stevcic, 1991). In a recent review of the family Eumedonidae Dana, 1853, Stevcic et al. (1988) placed Rhabdonotus in the subfamily Eumedoninae, allying it with the symbionts of echinoids like Echinoecus Rathbun, 1894, and Proechinoecus Ward, 1934, mainly because of its rounded carapace features.

As part of a comprehensive revision of the Eumedonidae, the authors examined specimens of Rhabdonotus from Thailand, Singapore, Australia, Philippines and Vanuatu. Three species of Rhabdonotus are now recognised, including two new species, one from Australia, and the other from the Philippines and Vanuatu. Both are described here.

A recent series of dredges conducted off the east coast of Singapore also resulted in the collection of a gravid female of Rhabdonotus pictus from which larvae were obtained. Comparisons of the $R$. pictus larvae were made with the known larvae of other species of eumedonids, viz. Harrovia longipes Lanchester, 1900, Harrovia albolineata Adams \& White, 1849, Echinoecus pentagonus Rathbun, 1894, and Zebrida adamsii White, 1847.

\section{Materials and methods}

The abbreviations G1 and G2 are used for the male first and second gonopods respectively. Specimens are deposited in the Nationaal Natuurhistorisch Museum, Leiden, The Netherlands (previously Rijksmuseum van Natuurlijke Histoire, RMNH); Natural History Museum, London England (previously British Museum Natural History, BMNH); Northern Territory Museum of Arts and Sciences, Darwin, Australia (NTM); Musèum National d'Histoire Naturelle, Paris, France (MNHN); Phuket Marine Biological Centre, Phuket, Thailand (PMBC); Queensland Museum, Brisbane, Australia (QM); Natur-Museum und Forschungs-Institut Senckenberg, Frankfurt-am-Main, Germany (SMF); Zoological Reference Collec- 
tion, Department of Zoology, National University of Singapore, Singapore (ZRC). The length of the carapace (cl) was measured from the tip of the rostrum to the posterior margin of the carapace; the width (cb) from one antero-posterior angle to the other. All length and width measurements are in millimeters. The term 'supra-orbital teeth' used in the present paper is equivalent to the 'lateral rostral lobule' used by other workers. 'Infra-orbital' teeth is equivalent to 'suborbital teeth'.

The gravid female of Rhabdonotus pictus, collected from its crinoid host, was maintained in an aquarium at $28^{\circ} \mathrm{C}$. The larvae released were preserved in Steedman's preservative (Griffiths et al., 1976). Appendages of larvae were dissected in glycerin with entomological needles and drawn with the aid of a camera lucida under dissecting and compound microscopes. Structural details were based on at least six specimens. Length of the carapace was measured from the tip of the rostrum to the posterior margin of the carapace. All measurements are in millimetres.

\section{Taxonomy \\ Eumedonidae Dana, 1853}

Rhabdonotus A. Milne Edwards, 1879

Rhabdonotus A. Milne Edwards, 1879: 107. de Man, 1887-1888: 325. - Balss, 1957: 1650. - Johnson, 1962: 285. - Serène \& Romimohtarto, 1963: 9, 12. - Wu, 1983: 318 [name in Chinese]. Stevcic et al., 1988: 1312, 1317. - Stevcic, 1991: 126.

Caphyra - Walker, 1887: 116 (part) [not Caphyra Guèrin, 1832].

Diagnosis. - Carapace rounded, dorsal surfaces very convex; rostrum pronounced but not elongate; supraorbital teeth present, frontal margin bilobed, separated by a cleft; regions poorly defined; surface of carapace smooth without granules except for the anterolateral and frontal margins; dorsal surface of cara- pace glabrous, not covered with pubescence. Antero- and posterolateral margins gradually merging; anterolateral margin entire or with epibranchial cleft and tooth. Antennules folding obliquely, ca. $45^{\circ}$ from horizontal. Second antennal segment slightly shorter than basal segment. Merus of first ambulatory leg more slender than others, dactylus elongated, slender, ca. 2 times length of that on other legs; dorsal margin of merus smooth, not cristate but can be tuberculated on the outer lobe; outer margins of carpus and propodus can be mildly or heavily tuberculated.

Type species. - Rhabdonotus pictus A. Milne Edwards, 1879, by monotypy.

Etymology. - The genus name was probably derived from the Greek "rhabdotos" for striped and "notos" for back, alluding to the transversely striped carapace pattern of the type species. Gender masculine.

Remarks. - The systematic position of Rhabdonotus has been quite ambiguous. The genus was first included in the family Xanthidae by A. Milne Edwards (1879), who allied it with the trapeziines. This was subsequently maintained by de Man (1888) and Balss (1957). However, Johnson (1962) indicated that Rhabdonotus perhaps belonged to the subfamily Eumedoninae (family Parthenopidae) due to its close association with crinoids and its general appearance. Johnson's suggestion (1962: 286) was probably prompted by $R$. Serène since he made reference to Serène's investigation of the problem. Subsequently, Serène \& Romimohtarto (1963) using Johnson's specimens from Singapore and field observations (from C. Sankarankutty, via a letter) transferred the genus to the Eumedoninae on the basis of its habits as an echinoderm symbiont and its external morphology. In the same study, Serène \& Romimohtarto (1963) also determined that Caphyra archeri Walker, 1887 (type locality Singapore), is a junior synonym of 
Rhabdonotus pictus A. Milne Edwards, 1879 (type locality Vietnam), noting the similarities in the descriptions and figures provided by Walker (1887) and A. Milne Edwards (1879). A synopsis of the taxonomic history of this species can be found in Stevcic (1991).

Stevcic et al. (1988), in reviewing the family Eumedonidae, recognised two subfamilies: Eumedoninae Dana, 1853, and a new subfamily, Ceratocarcininae. They referred the genus Rhabdonotus to the subfamily Eumedoninae, together with Echinoecus Rathbun, 1894, Eumedonus H. Milne Edwards, 1834, Gonatonotus Adams \& White, 1847, Proechinoecus Ward, 1934, and Zebrida White, 1847. This scheme of classification however, is probably incorrect because in Rhabdonotus the first leg is elongated and it is a crinoid symbiont, which allies it with other crinoid-associated genera like Harrovia Adams \& White, 1849, and Ceratocarcinus White, 1847. Other than Rhabdonotus, all other echinoecines (sensu Stevcic et al., 1988) are symbionts on echinoids. Only in the general form of the carapace does Rhabdonotus superficially resemble Echinoecus Rathbun, 1894.

Rhabdonotus previously contained only one species, $R$. pictus A. Milne Edwards, 1879. However, with the present revision, it now has three species, two of which are here regarded as new.

\section{Key to species}

1. Frontal margin with very pronounced cleft, frontal lobes triangular, supraorbital teeth not as distinct; infra-orbital teeth triangular; posterolateral margin straight; external angle of merus of third maxilliped rounded; dorsal margins of all ambulatory meri end with a subdistal triangular lobe .

Rhabdonotus xynon new species

- Frontal margin with shallower cleft, frontal lobes rounded, supra-orbital teeth distinct; infra-orbital teeth rounded; posterolateral margin more converging; external angle of merus of third maxilliped angular; dorsal margins of all ambulatory legs with a subdistal rounded lobe 2

2. Frontal margin and anterolateral margin with numerous strong tubercles, appearing serrated; epibranchial cleft and tooth usually present; posterolateral margin not as converging; surfaces of cheliped heavily tuberculated; ambulatory legs very hairy, outer margins of ambulatory carpus and propodus lined with strong spines .... ..... Rhabdonotus pilipes new species

- Frontal margin and anterolateral margin mildly tuberculated, not appearing serrated; epibranchial cleft and tooth usually absent in females and juveniles; posterolateral margin converging; surfaces of cheliped mildly tuberculated; ambulatory legs not distinctly hairy, outer margins of ambulatory carpus and propodus mildly tuberculated Rhabdonotus pictus

A. Milne Edwards, 1879

\section{Rhabdonotus pictus A. Milne}

Edwards, 1879

Figs. 1-4, 9, 10A-B

Rhabdonotus pictus A. Milne Edwards, 1879: 108, pl. 2: fig. 2, 2a [type locality "Cochinchine" = Vietnam]. - ?de Man, 1887-1888b: 325, 586 [Ambon, Moluccas = Maluku Islands, Indonesia]. - Johnson, 1962: 285 [Singapore]. - Serène \& Romimohtarto, 1963: 9, fig. 1C, 5, pl. 2: fig. F, G [Singapore]. - Sankarankutty, 1966: 347, 349, 352, fig. 1-4 [Gulf of Manaar, southeast India]. - Johnson, 1967:521 [list only]. - Serène, 1968: 63 [list only]. - Lundoer, 1974: 5 [Phuket Island, Thailand, Andaman Sea]. - Naiyanetr, 1980: 31 [list only]. - Shen et al., 1982: 147, fig. 5: 15, pl. 2: fig. 14 [Beibu Gulf = Gulf of Tonkin, China]. - Wu, 1983: 318 [name in Chinese]. 

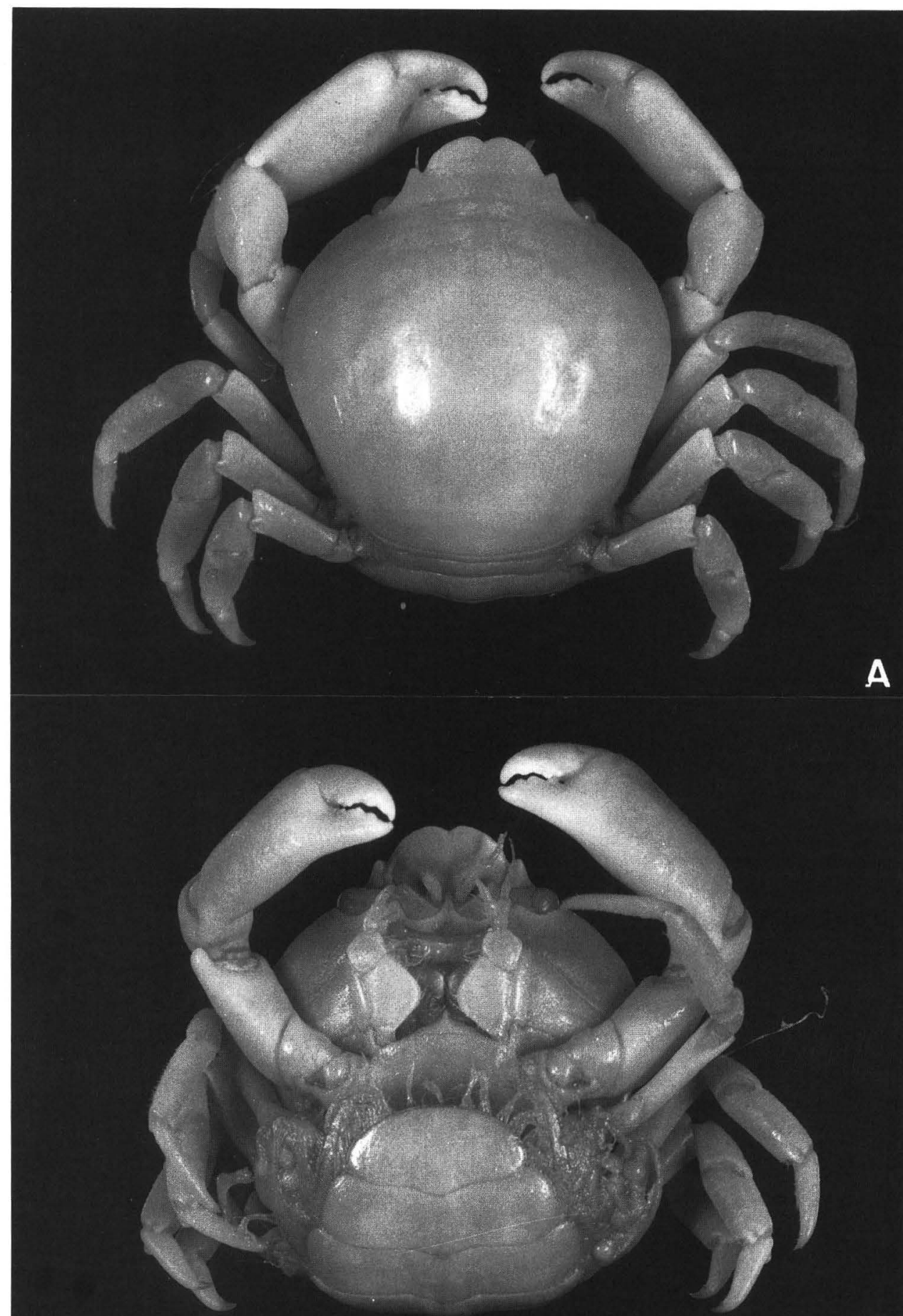

Fig. 1. Rhabdonotus pictus A. Milne Edwards, 1879, neotype male, cl $6.9 \mathrm{~mm}$, cb $6.4 \mathrm{~mm}$ (ZRC 1984.7862): A, dorsal view; $B$, ventral view. 


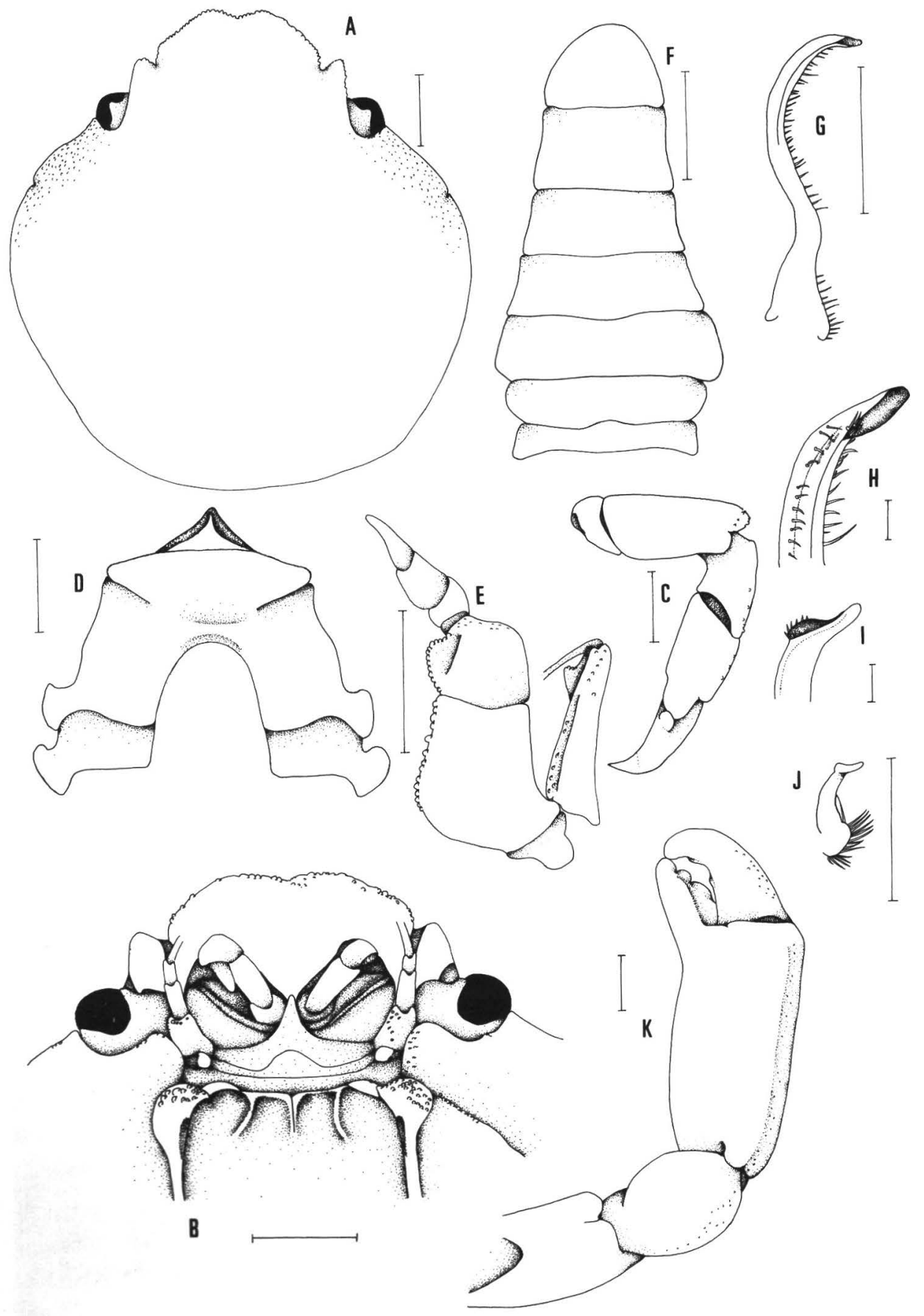

Fig. 2. Rhabdonotus pictus A. Milne Edwards, 1879, neotype male, cl $6.9 \mathrm{~mm}$, cb $6.4 \mathrm{~mm}$, (ZRC 1984.7862): A, carapace; B, face of carapace; $C$, right fourth ambulatory leg; $D$, anterior sternites; $\mathrm{E}$, left third maxilliped; F, abdomen; G, ventral view of left $\mathrm{G} 1 ; \mathrm{H}$, ventral view of tip of left $\mathrm{G} 1$; I, ventral view of tip of left $\mathrm{G} 2$; J, ventral view of left $\mathrm{G} 2 ; \mathrm{K}$, right cheliped. Scales for A-G, J-K = $1.0 \mathrm{~mm}$; for $\mathrm{H}-\mathrm{I}=0.1 \mathrm{~mm}$. 
- Dai et al., 1986: 166, fig. 99, pl. 22: fig. 7 [list only]. - Stevcic et al., 1988: 1312 [list only]. Dai \& Yang, 1991: 185, fig. 99, pl. 22: fig. 7 [list only].

Caphyra archeri Walker, 1887: 110, 116, pl. 9: fig. 4, 5 [type locality Singapore]. - Nobili, 1901: 11 [in key]; 1906: 188 [in key]. Balss, 1934: 506 [list only]. -Stephenson \& Campbell, 1960: 96 [in key], 105 [list only]. - Stephenson, 1962: 313 [list only]. Crosnier, 1962: 27 [in footnote]. Stephenson, 1972: 7 [in key], 25 [list only].

? Caphyra archeri - Leene, 1938: 144, 147 [list only].

Materials examined. - Neotype (for both Rhabdonotus pictus A. Milne Edwards, 1879, and Caphyra archeri Walker, 1887, here designated), Johore Shoal, Singapore, dredged, coll. D.S. Johnson, 17 June 1953, đ, cl 6.9 mm, cb $6.4 \mathrm{~mm}$ (ZRC 1984.7862).

Others. - Johore Shoal, Singapore, dredged, coll. D.S. Johnson, 17 June 1953, , cl $7.4 \mathrm{~mm}$, cb $6.8 \mathrm{~mm}$, (ZRC 1984.7863). - Johore Shoal, Singapore, dredged, coll. D.S. Johnson, 17 June 1953, 2 ơ, 2 ㅇ (ZRC 1984.7864-67). - Johore Shoal, Singapore, trawled, coll. D.S. Johnson, 42- 44 $\mathrm{m}, 15$ September 1955, 1 के (ZRC 1984.7861). - Johore Shoal, Singapore, dredged, on crinoid, coll. D.S. Johnson, 17 June 1954, 1 \& (NTM). - Johore Shoal, Singapore, dredged, coll. D.G.B. Chia, 20 m, 29 August 1994, 1 ㅇ (ZRC 1995.224). Johore Shoal, Singapore, dredged, B25, B66, coll. Singapore Fisheries Research Station, 1954-5, 2 б, 3 क (ZRC 1984.7868-7873). - Kuala Kedah, at Telok Bahang, near Muka Head, Penang, Malaysia, from fishing boat, trawled, coll. T.M. Wong, 3 May 1979, 1 đ, 2 ㅇ (ZRC 1989.2043-45). - Kuala Kedah, at Telok Bahang, near Muka Head, Penang, Malaysia, from fishing boat, trawled, coll. T.M. Wong, 3 May 1979, 1 ơ, 1 \& (RMNH 37261). - Off Batu Maung, Penang, Malaysia, from trawler, coll. K. Sagathevan, Jan 1983, 1 \%, cl 7.5 mm, cb 7.2 mm (ZRC 1989.2046). - Phuket, Thailand, bottom trawl, subtidal, 22 November 1972, 1 ㅇ
(PMBC 2250). - Ceylon (= Sri Lanka), coll. W.H. Holdsworth, 1 , cl $9.7 \mathrm{~mm}$, cb $9.4 \mathrm{~mm}$, (re-registered as BMNH 1965.1.6.1) (old registration number, BMNH 75.14). - Amboina, Moluccas, Indonesia, on comatulid, coll. J. Brock, JulySeptember 1885, 1 우 (SMF).

Diagnosis. - Carapace very smooth, except for frontal, anterolateral margins of carapace. Frontal margin bilobed, lobes rounded, cleft between lobes shallow. Supra-orbital teeth distinct. Infra-orbital teeth rounded. Anterolateral margin maybe entire especially in adult females, or with weak epibranchial cleft and tooth in adult males; antero- and posterolateral margins not clearly demarcated; posterolateral margin converging and rounded. Third maxilliped smooth except for tuberculated anterior and inner margins of merus and inner margin of ischium; external angle of merus angular. Cheliped subequal, surfaces of the chelipeds appearing mildly tuberculated. Ambulatory legs relatively little hair; dorsal margins of meri end in a rounded lobe; outer margins of carpus and propodus with few tubercles, appearing rather smooth.

Etymology. - The species name "pictus" was probably derived from Latin meaning colourful, possibly alluding to the two tone stripes on the carapace. Gender masculine.

Remarks. - The figure of A. Milne Edwards (1879: pl. 2, 2a) featured the carapace of his specimen bearing many transverse stripes of equal length reaching the posterior margin, which seems unusual. Though the first four stripes do agree with that of the specimens examined here, the posterior ones certainly do not (see Fig. 10A, B). At the cardiac region there is usually a dark concentric ring enveloped by dark stripes along the posterolateral and posterior margins. The differences could be due to the fact that A. Milne Edwards (1879) was examining a preserved specimen whose colour has 

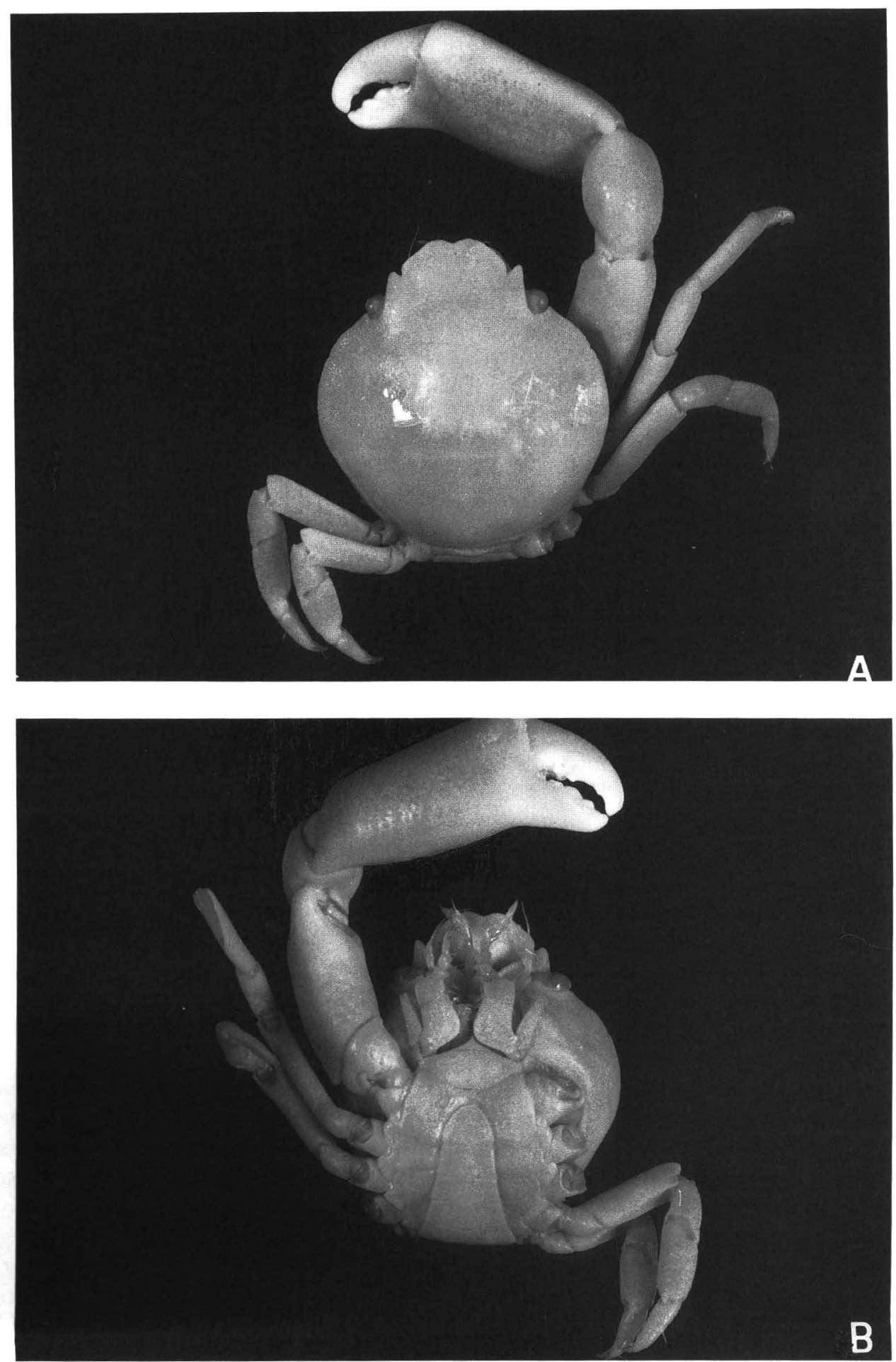

Fig. 3. Rhabdonotus pictus A. Milne Edwards, 1879, female, cl $7.4 \mathrm{~mm}$, cb $6.8 \mathrm{~mm}$ (ZRC 1984.7863): A, dorsal view; $B$, ventral view. 
been leached by preservatives and/or desiccation, thus rendering the markings faded and unclear. Some preserved specimens, examined by the present authors, whose dark pigmentation has mostly disappeared, bear only an outline of the remnant transverse stripes and closely resemble the figure of A. Milne Edwards (1879: pl. 2, 2a). We are confident from A. Milne Edwards' description (1879: 6) that the transverse stripes are red in colour, which agrees with our specimens (see Fig. $10 \mathrm{~A}, \mathrm{~B})$. The other disparity in the figure of A. Milne Edwards (1879: pl. 2, 2a) is the apparent sharpness of the left frontal lobe as compared to the right. But in all other aspects, his figure agrees with our specimens, and we have no doubt about their conspecificity.

De Man (1887-8: 325) reported a very large female of $R$. pictus (cl $11.5 \mathrm{~mm}$, cb $10.6 \mathrm{~mm}$ ), collected from a comatulid in Ambon, Indonesia, as bearing red lines on the legs. This condition is not observed in any of the specimens examined here. The authors have examined de Man's specimen (SMF) - its red pigmentation has faded (if it existed before). Except for this unusual colouration, in all other aspects, this specimen agrees well with the current concept of the species. For the moment, it is retained in $R$. pictus.

The records by Johnson (1962) and Serène \& Romimohtarto (1963) from Singapore have been discussed earlier on.

Sankarankutty (1966) first recorded the species from southern India, and his description of the colour markings fit well with our present definition of $R$. pictus. From his simplified illustration, all aspects agree with the current concept of the species except for the frontal lobes which appear to be rather pointed. This feature is also seen in a Sri Lankan specimen (BMNH 1965.1.6.1); being the largest specimen we examined (cl $9.7 \mathrm{~mm}$, cb $9.4 \mathrm{~mm}$ ), it has very sharp and rather serrated frontal lobes (see Fig. 4I) almost approaching that of $R$. xynon new species (see Fig 8A). However, in the other aspects like the last ambulatory leg, third maxilliped (see Fig. 4J, k) and colour, the specimen falls within the present definition of the species. Unless more specimens are obtained and studied, the Sri Lanka specimen is here regarded as representing the extreme known variation in R. pictus.

The Thai specimen (PMBC 2250) examined was probably the one reported by Lundoer (1974). Shen et al. (1982) reported two specimens from Beibu Gulf (= Gulf of Tonkin), China. This is perhaps the first report of specimens collected from near type locality (Vietnam) since the description of the species. Unfortunately, the specimens could not be located (Dai A. Y., pers. comm.). However, from Shen et al.'s description and figure (1982: 147, fig. 5: 15, pl. 2: fig. 14; see also Dai et al., 1986; Dai \& Yang. 1991), the Gulf of Tonkin specimens seem to agree well with what is here recognised as $R$. pictus.

There had been some confusion as to how Caphyra archeri Walker, 1887, should be classified. Several workers on the Portunidae (e.g. Stephenson \& Campbell, 1960; Crosnier, 1962) have queried the placement of Walker's species in the genus Caphyra. Serène \& Romimohtarto (1963) were the first to suggest that the resemblance between Caphyra and Rhabdonotus is superficial, and $C$. archeri is a junior synonym of $R$. pictus.

Serène \& Romimohtarto (1963) stated that the type(s) of $R$. pictus A. Milne Edwards, 1879 could not be found in the MNHN and should be considered as lost. In a recent visit to the MNHN, the present authors were also unsuccessful in locating the type specimen(s). At the same time, D. Guinot has also confirmed this predicament in a letter to the authors on 29 November 1994, noting “ ... le type Rhabdonotus pictus ne se trouve pas au MNHN...". In the absence of the type material and with two new species being assigned to this previously monotypic ge- 


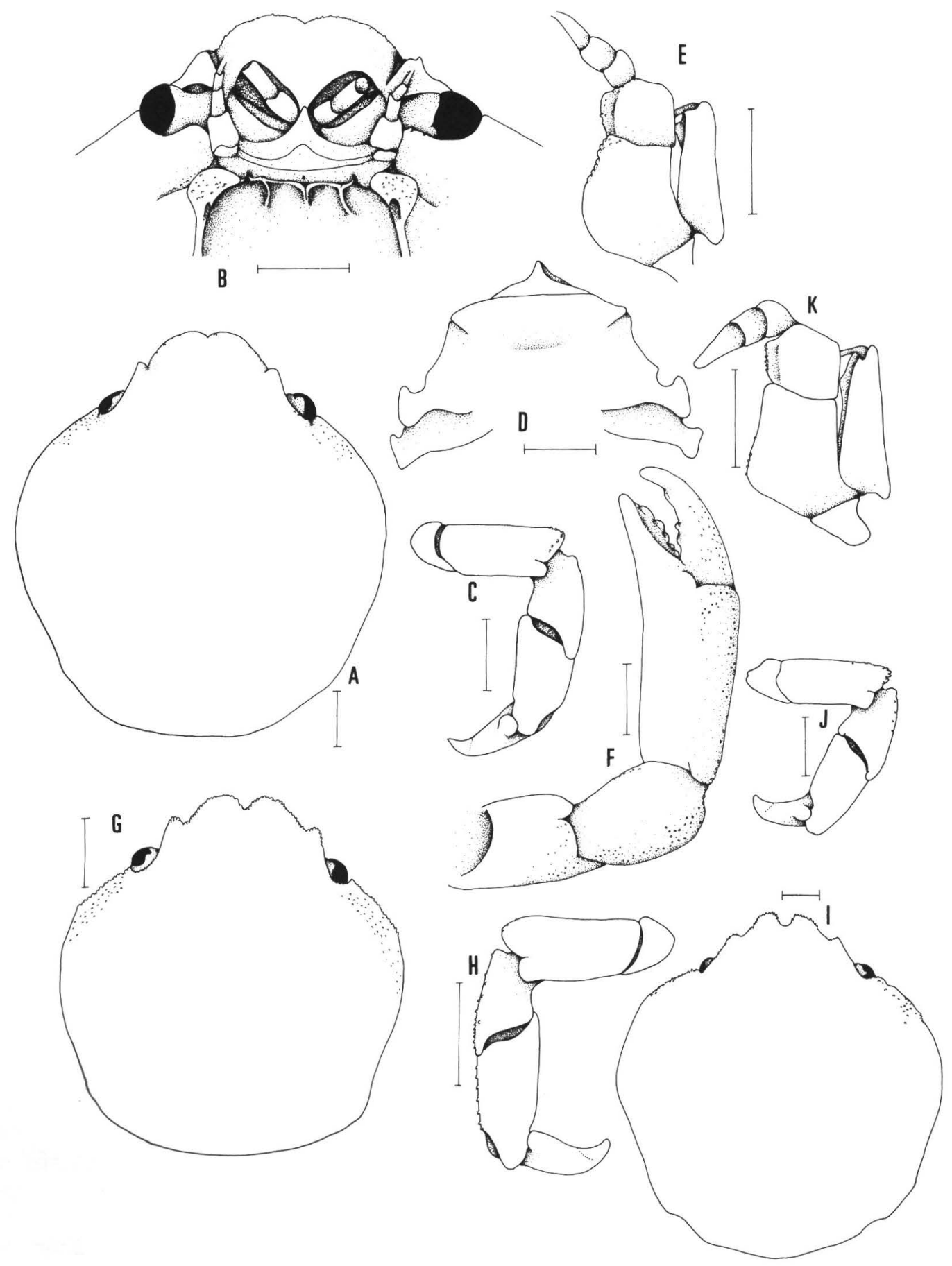

Fig. 4. Rhabdonotus pictus A. Milne Edwards, 1879. A-F, female, cl $7.4 \mathrm{~mm}$, cb $6.8 \mathrm{~mm}$, (ZRC 1984.7863): A, carapace; $B$, face of carapace; C, right fourth ambulatory leg; D, anterior sternites; $\mathrm{E}$, left third maxilliped; F, right cheliped. G-H, female, cl. $5.3 \mathrm{~mm}$, cb $4.8 \mathrm{~mm}$, (ZRC 1995.224): G, carapace; $\mathrm{H}$, left fourth ambulatory leg. I-K, female, cl $9.7 \mathrm{~mm}$, cb 9.4 mm, (BMNH 1965.1.6.1): I, carapace; J, left fourth ambulatory leg; $\mathrm{K}$, left third maxilliped. Scales $=1.0 \mathrm{~mm}$. 
nus, the designation of a neotype for $R$. pictus A. Milne Edwards, 1879, is essential to ensure a stable taxonomy. Furthermore, the type of the junior synonym Caphyra archeri Walker, 1887, is also missing from the BMNH (pers. obs.; P. Clark, pers. comm.). The authors therefore here propose that a male specimen from Singapore (ZRC 1984.7862) be designated as the simultaneous neotype of both Rhabdonotus pictus A. Milne Edwards, 1879, and Caphyra archeri Walker, 1887. It is unfortunate that there are no extant specimens of $R$. pictus collected from the type locality, Vietnam, but the present lot of specimens from Singapore, Malaysia and Thailand, fit the descriptions and figures of A. Milne Edwards (1879) and Walker (1887), and there is little doubt of their conspecificity. In any case, the present neotype selection would fit the current concept of the species, which follows Serène \& Romimohtarto (1963).

Rhabdonotus pictus is closely related to $R$. pilipes new species, but the former species appears to be a smoother species on the whole, with distinctly less hairy ambulatory legs (see Table 1 for more differences). Granules, if present in $R$. pictus, are low, small and weak (see Figs. $2 \mathrm{~A}, \mathrm{E}, \mathrm{K}, 4 \mathrm{~A}, \mathrm{E}, \mathrm{F})$, very unlike the kind of granules seen in $R$. pilipes new species (see Fig. 6A, E, F) which are large and strong, making the frontal and anterolateral margins appear serrated. For both species, it appears that the juvenile forms are usually more granulated when young (see Fig. 4G-H), as it is evident in the recently collected $R$. pictus (ZRC 1995.224) from Johore Shoal, Singapore. However, this specimen is still relatively glabrous on the ambulatory legs as compared to the distinctly hairy juveniles of $R$. pilipes new species

There is some variation in the presence or absence of the epibranchial cleft and tooth in both species. In most cases, for the adults, this character can be used to separate $R$. pictus from $R$. pilipes new species, the epibranchial cleft and tooth being more prominent in the latter. In most female specimens of $R$. pictus examined, the epibranchial cleft and tooth are usually absent. It is, however, not the case for $R$. pilipes new species. Of all the perfect specimens (seven females and one male) examined, six specimens bear the epibranchial cleft and tooth. Only two female specimens (NTM Cr 008807, ZRC 1994.4226) do not have a distinct epibranchial cleft and tooth. It would thus seem that the presence of the epibranchial cleft and tooth is usually more pronounced in $R$. pilipes new species.

In $R$. pictus, the outer margins of the ambulatory carpus and propodus are only mildly tuberculated (see Fig. 2C, 4C) as compared to those of $R$. pilipes new species, which are lined with strong tubercles (see Fig. 6C). Although the smaller specimens of $R$. pictus (ZRC 1995.224, ZRC 1984.7867) are more tuberculated (see Fig. 4H) than the adult forms, the extent of tuberculation still does not reach the degree of $R$. pilipes new species.

Thus, $R$. pictus can be separated from $R$. pilipes new species with the use of the following characters: 1 ) smoother appearance in general, on all surfaces; 2) very weak (or absence of) epibranchial cleft and tooth; 3) the posterolateral margins are more converging; 4) relatively few hairs on the ambulatory legs; 5) the outer margins of the ambulatory carpus and propodus are smooth or mildly tuberculated and 6) colour pattern (see colour remarks for $R$. pictus).

Host records. - Host records for $R$. pictus are not well documented. Most workers merely mentioned that the possible host could be comatulid crinoids without providing names of the hosts (de Man, 1887-8; Johnson, 1962). Contrary to others, Sankarankutty (1966) commented that the host could possibly be an anthozoan, Virgularia sp., instead of a crinoid. The host of the recently collected specimen (ZRC 1995.224) is a crinoid, prob- 
ably, Cyllometra manca, family Colobometridae.

Distribution. - Known from localities in: Gulf of Manaar, Sri Lanka, Phuket, Penang, Singapore, Vietnam, Gulf of Tonkin and Ambon.

Colour. - Based on the colour slide of a Penang specimen and a freshly collected Singapore specimen (ZRC 1995.224): Carapace with 4 main transverse maroon stripes on anterior dorsal half of carapace; first stripe narrow between supraorbital lobes; second to fourth stripes medially broadest with median part pale yellow. Lateral and posterior margins of carapace with a continuous dark maroon band which is confluent with transverse stripes. Posterior half of carapace with a broad oval ring (dark maroon margin, pale yellow centre), the edges of which may reach lateral maroon band (see Fig. 10A, B).

Biology. - The recently collected $R$. pictus (ZRC 1995.224) with its host were observed in the aquarium. It was usually found on the oral side of the crinoid clinging onto the host using its last two ambulatory legs. The crab was seen constantly scraping mucus off the arms of the host with the help of its chelipeds and first two ambulatory legs. Thereafter it would feed on the mucus.

\section{Rhabdonotus pilipes new species}

Figs. 5, 6, 10C

Rhabdonotus pictus - Stevcic, 1991: 126 (part) [Western Australia] [not Rhabdonotus pictus A. Milne Edwards, 1879]

Material examined. - Holotype: West of Weipa, northern Queensland, Australia, stn (= station) $46,12^{\circ} 27.4$ 'S, $141^{\circ} 14.9^{\prime} \mathrm{E}$, dredge, coll. A.J. Bruce, vessel F.R.V. "Southern Surveyor", 40 m, 27 November 1991, 1 \%, cl $7.2 \mathrm{~mm}$, cb $6.8 \mathrm{~mm}$ (NTM Cr008806).

Paratypes. - Gulf of Carpentaria, northern Queensland, Australia, stn 36, $13^{\circ} 2^{\prime} \mathrm{S}, 139^{\circ} 22.2^{\prime} \mathrm{E}$, dredge, coll. A.J. Bruce, vessel F.R.V. "Southern Surveyor", $58 \mathrm{~m}$, on Heterometra crenulata, 25 November 1991, 1 \%, cl $6.4 \mathrm{~mm}$, cb $6.1 \mathrm{~mm}$ (NTM Cr008863). - Gulf of Carpentaria, northern Queensland, Australia, stn 36, $13^{\circ} 2^{\prime} \mathrm{S}, 139^{\circ} 22.2^{\prime} \mathrm{E}$, dredge, coll. A.J. Bruce, vessel F.R.V. "Southern Surveyor", $58 \mathrm{~m}, 25$ November 1991, 1 \% , cl $7.6 \mathrm{~mm}$, cb $7.1 \mathrm{~mm}$ (ZRC 1994.4226). - Gulf of Carpentaria, northern Queensland, Australia, $13^{\circ} 01.3^{\prime} \mathrm{S}, 140^{\circ} 12.0^{\prime} \mathrm{E}$, dredge, marine, subtidal, coll. Commonwealth Scientific and Industrial Research Organization (CSIRO), vessel F.R.V. "Southern Surveyor", 47-63 m, 1 December 1990, 3 ค, cl $6.3 \mathrm{~mm}$, cb $6.0 \mathrm{~mm}, \mathrm{cl} 5.9 \mathrm{~mm}$, cb 5.5 $\mathrm{mm}, 1$ badly damaged (QM W18709). West of Weipa, northern Queensland, Australia, stn $46,12^{\circ} 27.4^{\prime} \mathrm{S}, 141^{\circ} 14.9^{\prime} \mathrm{E}$, dredge, coll. A.J. Bruce, vessel F.R.V. "Southern Surveyor", 40m, 27 November 1991, 1 \%, cl $7.4 \mathrm{~mm}$, cb $7.0 \mathrm{~mm}$ (NTM Cr008805). - West of Weipa, northern Queensland, Australia, stn 42, $12^{\circ} 24.8^{\prime} \mathrm{S}$, $140^{\circ} 42.4^{\prime} \mathrm{E}$, dredge, coll. A.J. Bruce, vessel F.R.V. "Southern Surveyor", 58 m, 26 November 1991, 1 \%, cl $5.7 \mathrm{~mm}$, cb $5.5 \mathrm{~mm}$ (NTM Cr 008807).

Others. - Northwest Shelf, western Australia, stn 0483 B7 BT, $19^{\circ} 30.8^{\prime} \mathrm{S}$, $118^{\circ} 49.3^{\prime} \mathrm{E}$, dredge, coll. T. Ward, R.V. "Soela", 39 m, 30 August 1983, 1 ò, cl 5.2 $\mathrm{mm}$, cb 4.9 mm (NTM Cr0007875).

Diagnosis. - Frontal and anterolateral margins of carapace, anterior and inner margins of third maxillipedal merus, inner margin of third maxillipedal ischium and surfaces of the chelipeds heavily tuberculated. Anterolateral margin rarely entire; antero- and posterolateral margins usually demarcated with epibranchial cleft and tooth; posterolateral margin appearing slightly straight. Ambulatory legs very hairy; outer margins of carpus and propodus with strong tubercles, appearing spiny.

Etymology. - The name "pilipes" is 

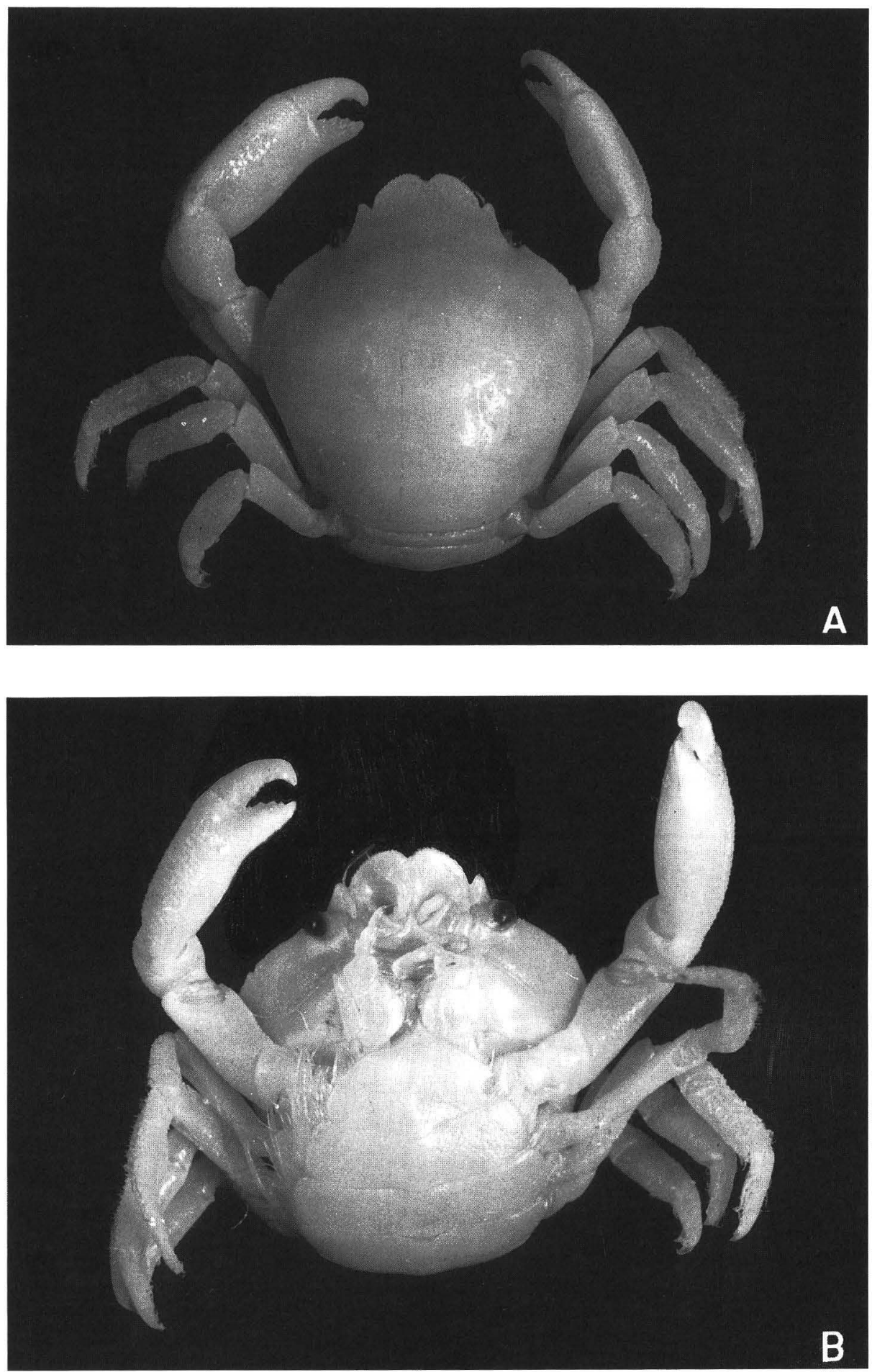

Fig. 5. Rhabdonotus pilipes new species, holotype female, cl $7.2 \mathrm{~mm}$, cb $6.8 \mathrm{~mm}$ (NTM Cr008806): A, dorsal view; $B$, ventral view. 


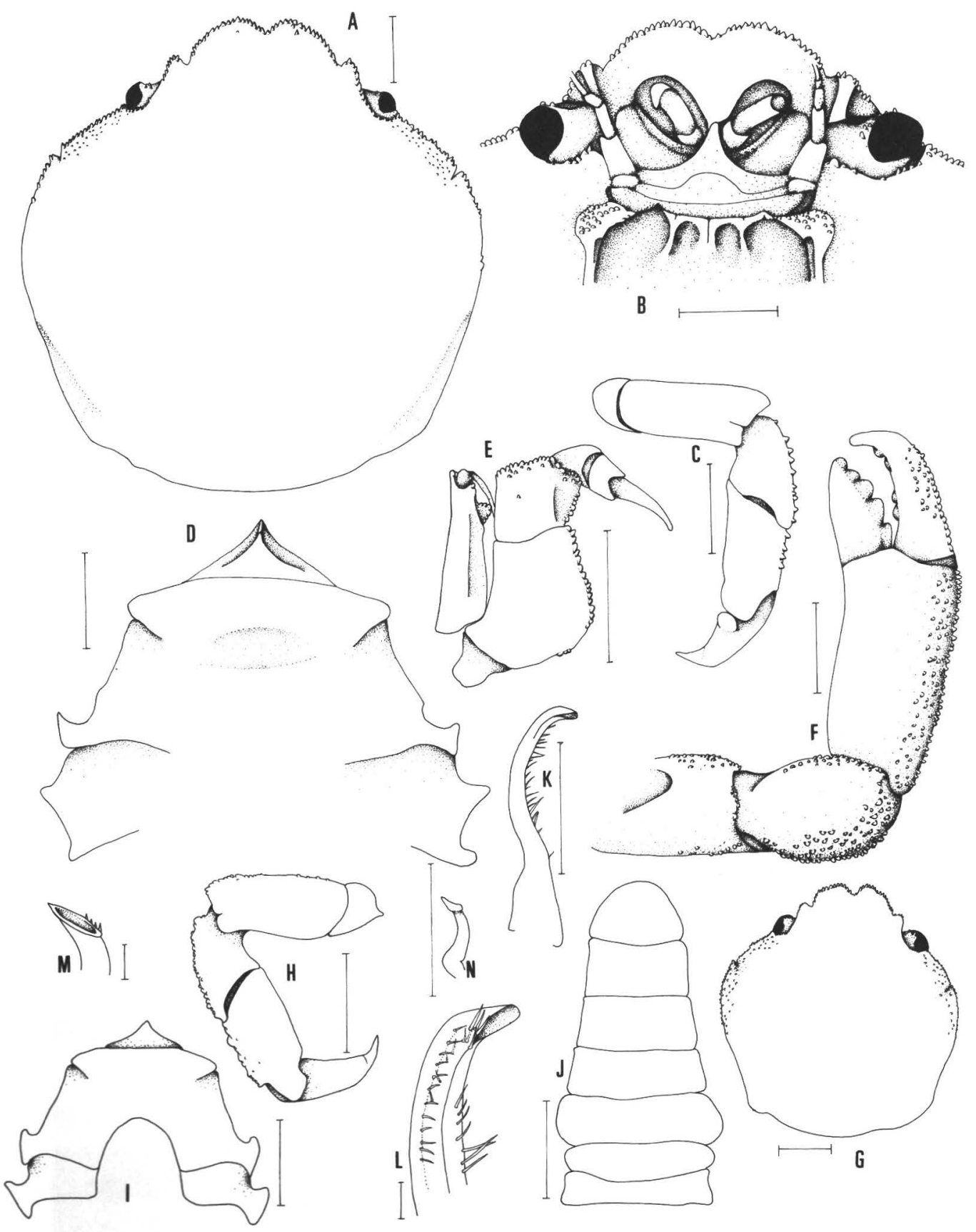

Fig. 6. Rhabdonotus pilipes new species. A-F, holotype female, cl $7.2 \mathrm{~mm}$, cb $6.8 \mathrm{~mm}$, (NTM Cr008806): A, carapace; B, face of carapace; C, right fourth ambulatory leg; D, anterior sternites; $\mathrm{E}$, right third maxilliped; F, right cheliped. G-N, male, cl $5.2 \mathrm{~mm}$, cb $4.9 \mathrm{~mm}$, (NTM Cr007875): $\mathrm{G}$, carapace; $\mathrm{H}$, left fourth ambulatory leg; I, anterior sternites; J, abdomen; $\mathrm{K}$, ventral view of left $\mathrm{G} 1$; $\mathrm{L}$, ventral view of tip of left $\mathrm{G} 1 ; \mathrm{M}$, ventral view of tip of left $\mathrm{G} 2 ; \mathrm{N}$, ventral view of left $\mathrm{G} 2$. Scales for A-K, N = $1.0 \mathrm{~mm}$; for $\mathrm{L}-\mathrm{M}=0.1 \mathrm{~mm}$. 
derived from Latin 'pilus' for hair, in combination with 'pes' for legs alluding to the hairy legs. Used as a noun in apposition.

Remarks. - The differences between $R$. pictus and $R$. pilipes new species have been discussed in the earlier section and outlined in Table 1 and the key. In general, as mentioned before, $R$. pilipes new species, compared to $R$. pictus, is a more granulated and pilose species. Although there is variation in the extent of tuberculation within species, when comparing specimens of similar sizes between $R$. pilipes new species, and $R$. pictus, the former species is still distinctly more granulated.

The specimen (Fig. 6G) reported by Stevcic (1991: 126) from Western Australia was re-examined. Being a small male, it has a distinct epibranchial cleft and tooth, and in all other aspects agree with the current concept of R. pilipes new species.

Host records. - Known only from a comatulid crinoid, Heterometra crenulata.

Distribution. - Known only from the Gulf of Carpentaria, Northwest Shelf, Australia.

Colours. - Based on the colour slide of a live specimen, $R$. pilipes new species, closely resembles $R$. pictus in the colour pattern. The differences however, are: 1 ) the first transverse stripe, which runs between the two inner supra-orbital teeth, appears to be broader, diffused and not as distinctive; 2 ) the posterior margin seems not to have any markings; 3 ) the chelipeds bear no markings; 4) all stripes are brown (vs. maroon in R. pictus), and the centre of the stripes do not appear as pale and the outline is only slightly darker (Fig. 10C).

\section{Rhabdonotus xynon new species}

$$
\text { Figs. 7, 8, 10D }
$$

Material examined. - Holotype: Philippines, stn $\mathrm{CP} 121,12^{\circ} 08^{\prime} \mathrm{N}, 121^{\circ} 18^{\prime} \mathrm{E}$, dredge, coll. MUSORSTOM 3, vessel N.O.
"Coriolis", 73-84m, 3 June 1985, 1 \%, cl $8.4 \mathrm{~mm}$, cb $7.7 \mathrm{~mm}$ (MNHN).

Other. - Vanuatu, stn CP1027, $17^{\circ} 53.05^{\prime} \mathrm{S}, 168^{\circ} 39.35^{\prime} \mathrm{E}$, dredge, coll. MUSORSTOM 8, 550-571m, 28 September 1994, 1 \%, cl $5.2 \mathrm{~mm}$, cb $4.9 \mathrm{~mm}$ (MNHN).

Diagnosis. - Carapace appears to be very smooth, except for frontal, anterolateral margins of carapace and surfaces of the chelipeds heavily tuberculated. Frontal margin bilobed, lobes triangular or slightly rounded, cleft between lobes deeper. Supra-orbital teeth less distinct. Infra-orbital teeth triangular. Anterolateral margin may be entire, antero- and posterolateral margins appear gradually merging; antero- and posterolateral margins maybe demarcated with small epibranchial cleft and very small, weak tooth; posterolateral margin straight. Third maxilliped mildly granulated; external angle of merus rounded. Ambulatory legs hairless; dorsal margins end in a triangular lobe; outer margins of carpus and propodus with few tubercles.

Etymology. - The species name "xynon" is derived from Greek meaning companion, alluding to the close association of the crab with crinoid host. Used as a noun in apposition.

Remarks. - Through the courtesy of Dr. A. Crosnier of the ORSTOM, two specimens collected from the Philippines and Vanuatu were sent to us for study. These two specimens are found to be different from the earlier two species in the aspects of: 1) the frontal lobes are more triangular instead of rounded thus the cleft between the two lobes appears to be deeper; 2) the supra-orbital teeth are less distinct; 3 ) the infra-orbital teeth are triangular instead of rounded; 4) the posterolateral margins are straight; 5 ) the external angle of the merus of the third maxilliped is rounded instead of angular; 6) the dorsal margins of all ambulatory 


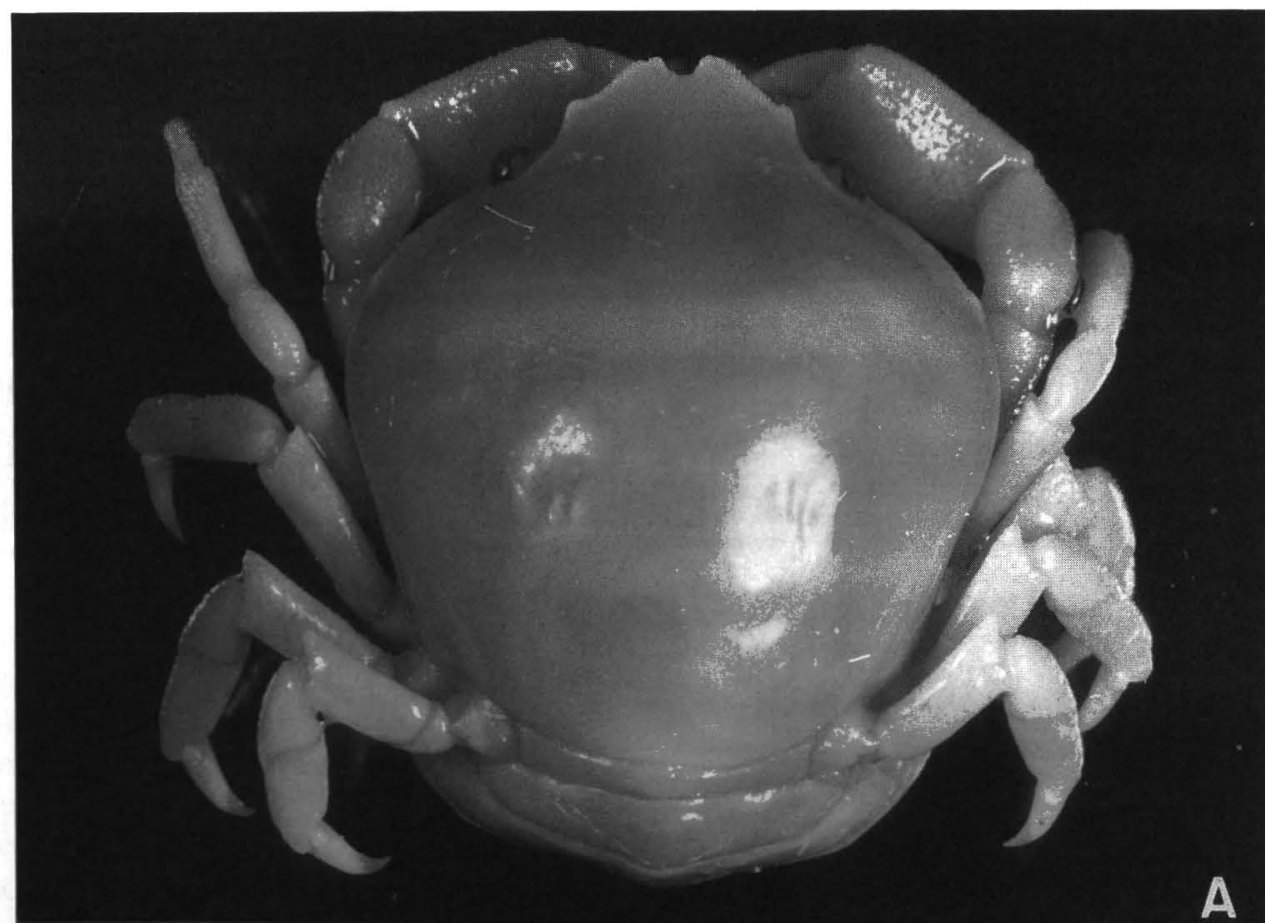

Fig. 7. Rhabdonotus xynon new species, holotype female, cl $8.4 \mathrm{~mm}$, cb $7.7 \mathrm{~mm}$ (MNHN): A, dorsal view; $B$, ventral view. 
Table 1. Differences between Rhabdonotus pictus A. Milne Edwards, 1879, R. pilipes new species and $R$. xynon new species.

\begin{tabular}{|c|c|c|c|}
\hline & Rhabdonotus pictus & R. pilipes & R. xynon \\
\hline Frontal margin & $\begin{array}{l}\text { Mildly tuberculated; bilobed, } \\
\text { lobes rounded; cleft between } \\
\text { lobes shallow (Fig. 2A, 4A, 4G) }\end{array}$ & $\begin{array}{l}\text { Heavily tuberculated, } \\
\text { margin appears serrated; } \\
\text { bilobed, lobes rounded; cleft } \\
\text { between lobes shallow (Fig. } \\
6 \text { A) }\end{array}$ & $\begin{array}{l}\text { Heavily tuberculated, } \\
\text { margin appears serrated; } \\
\text { bilobed, lobes more } \\
\text { triangular; cleft between } \\
\text { lobes deeper (Figs. } 8 \mathrm{~A}, 8 \mathrm{G} \text { ) }\end{array}$ \\
\hline Supraorbital teeth & Distinct (Figs. 2A, 4A, 4G) & Distinct (Fig. 6A) & Less distinct (Fig. 8A) \\
\hline Infraorbital teeth & Rounded & Rounded & Triangular \\
\hline Anterolateral margin & $\begin{array}{l}\text { Lined with flat and small } \\
\text { granules (Figs. 2A, 4A, 4G) }\end{array}$ & $\begin{array}{l}\text { Heavily tuberculated with } \\
\text { tall granules, margin } \\
\text { appearing serrated (fig. 6A) }\end{array}$ & $\begin{array}{l}\text { Heavily tuberculated with } \\
\text { tall granules (Fig. 8A) }\end{array}$ \\
\hline Epibranchial cleft & $\begin{array}{l}\text { More often present in adult } \\
\text { males than in females; in } \\
\text { adult specimens than } \\
\text { juveniles (Figs. } 2 \mathrm{~A}, 4 \mathrm{~A}, 4 \mathrm{G} \text { ) }\end{array}$ & $\begin{array}{l}\text { Very often present in } \\
\text { females (Fig. 6A) }\end{array}$ & $\begin{array}{l}\text { May be present in small } \\
\text { females (Fig 8G) }\end{array}$ \\
\hline Epibranchial tooth & $\begin{array}{l}\text { Very small and weak tooth } \\
\text { (Fig. 2A) }\end{array}$ & Stronger (Fig. 6A) & $\begin{array}{l}\text { May be present in small } \\
\text { females (Fig. } 8 \mathrm{G} \text { ) }\end{array}$ \\
\hline Posterolateral margin & Converging (Figs. 2A, 4A, 4G) & Slightly straighter (Fig. 6A) & Straight (Fig. 8A) \\
\hline \multicolumn{4}{|l|}{ Third maxilliped: } \\
\hline $\begin{array}{l}\text { 1. Anterior and inner } \\
\text { margins of merus }\end{array}$ & Usually tuberculated & $\begin{array}{l}\text { Usually heavily } \\
\text { tuberculated }\end{array}$ & $\begin{array}{l}\text { Not tuberculated (mildly } \\
\text { tuberculated in young) }\end{array}$ \\
\hline $\begin{array}{l}\text { 2. External angle of } \\
\text { merus }\end{array}$ & Quadrate & Quadrate & Rounded \\
\hline 3. Inner margin of ischium & Tuberculated (Figs. 2E, 4E) & $\begin{array}{l}\text { Heavily tuberculated (Fig. } \\
6 \mathrm{E})\end{array}$ & $\begin{array}{l}\text { Not tuberculated (mildly } \\
\text { tuberculated in young) (Fig. } \\
8 \mathrm{E} \text { ) }\end{array}$ \\
\hline Cheliped & $\begin{array}{l}\text { Mildly tuberculated with flat } \\
\text { granules (Figs. } 2 \mathrm{~K}, 4 \mathrm{~F} \text { ) }\end{array}$ & $\begin{array}{l}\text { Heavily tuberculated with } \\
\text { tall granules (Fig. } 6 \mathrm{~F} \text { ) }\end{array}$ & $\begin{array}{l}\text { Heavily tuberculated with } \\
\text { tall granules (Fig. 8F) }\end{array}$ \\
\hline $\begin{array}{l}\text { Dorsal margins of all } \\
\text { ambulatory legs end in a } \\
\text { triangular lobe }\end{array}$ & Absent & Absent & Present \\
\hline $\begin{array}{l}\text { Hairiness of ambulatory } \\
\text { legs }\end{array}$ & Slightly hairy & Very hairy & Not hairy \\
\hline $\begin{array}{l}\text { Outer margins of } \\
\text { ambulatory carpus and } \\
\text { propodus }\end{array}$ & $\begin{array}{l}\text { Mildly granulated (more } \\
\text { granulated in juveniles) (Figs. } \\
2 \mathrm{C}, 4 \mathrm{C}, 4 \mathrm{H})\end{array}$ & $\begin{array}{l}\text { Lined with strong tubercles } \\
\text { (Fig. 6C) }\end{array}$ & $\begin{array}{l}\text { Carpus mildly granulated; } \\
\text { propodus appears smooth } \\
\text { (Fig. } 8 \mathrm{C} \text { ) }\end{array}$ \\
\hline Colour pattern & $\begin{array}{l}\text { Outer and inner margins of } \\
\text { chelipeds bear two parallel } \\
\text { stripes; all stripes are red or } \\
\text { dark brown in color; in } \\
\text { transverse stripes } 2-4 \text { and } \\
\text { concentric ring, centre of } \\
\text { stripes appearing pale yellow } \\
\text { (Fig. 10A, B) }\end{array}$ & $\begin{array}{l}\text { Chelipeds bear no markings; } \\
\text { all stripes are brown in } \\
\text { colour, centre of stripes do } \\
\text { not appear as pale (Fig. } \\
\text { 10C) }\end{array}$ & $\begin{array}{l}\text { Overall colour appearing } \\
\text { purplish-brown. Possible pale } \\
\text { reddish-orange markings } \\
\text { along the frontal and } \\
\text { anterolateral margins, } \\
\text { cardiac region and chelipeds } \\
\text { (Fig. 10D) }\end{array}$ \\
\hline
\end{tabular}




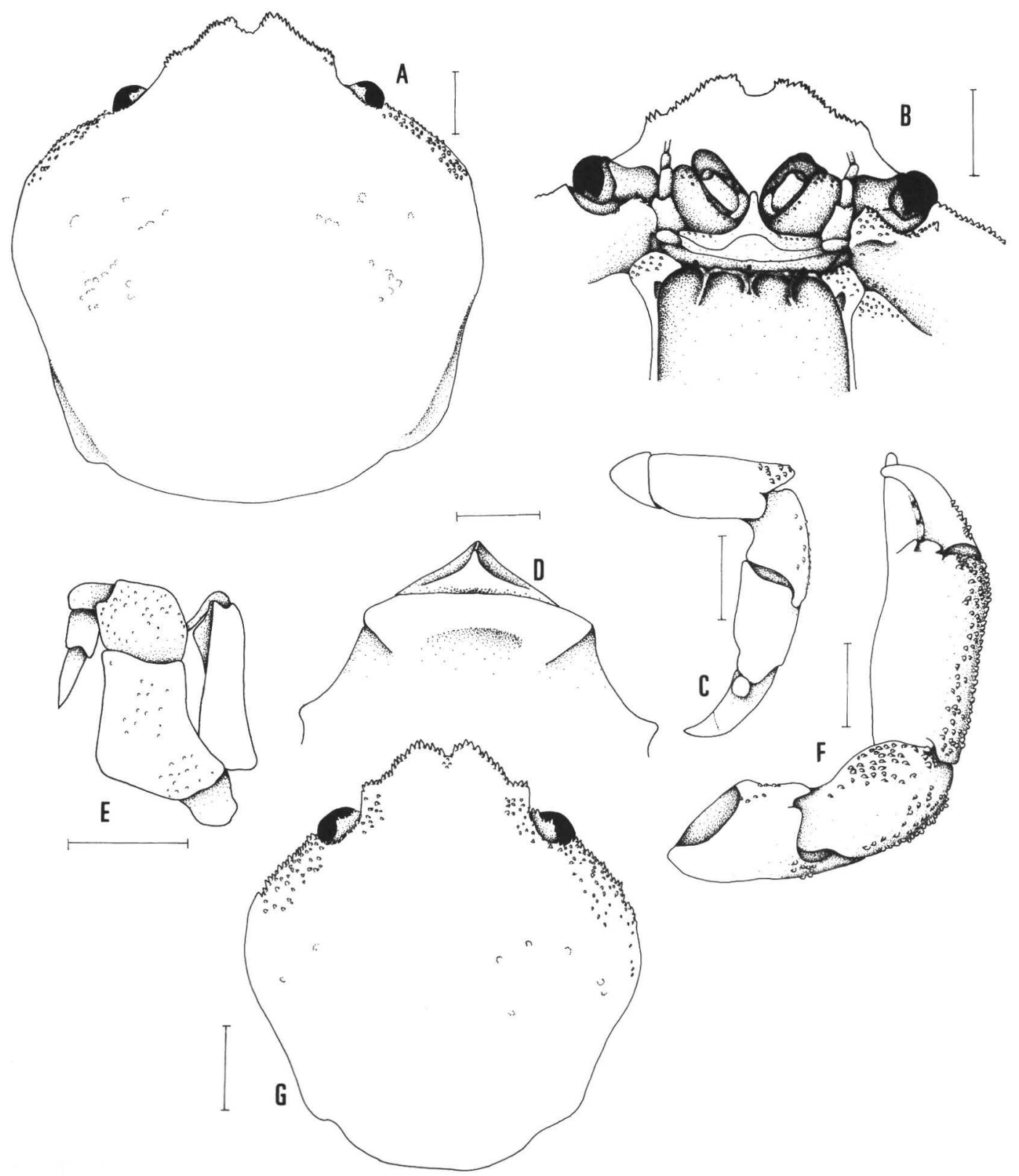

Fig. 8. Rhabdonotus xynon new species, A-F, holotype female, cl $8.4 \mathrm{~mm}$, cb $7.7 \mathrm{~mm}$, (MNHN): A, carapace; B, face of carapace; C, right fourth ambulatory leg; D, anterior sternites; $\mathrm{E}$, left third maxilliped; F, right cheliped. G, female, cl $5.2 \mathrm{~mm}, \mathrm{cb} 4.9 \mathrm{~mm}$, (MNHN), carapace. Scales $=1.0$
$\mathrm{~mm}$.

meri end in a triangular lobe; 7) ambulatory legs are not hairy, 8) only the outer margin of the ambulatory carpus is mildly tuberculated and 9) colour pattern (see
Table 1).

There are some differences between the smaller Vanuatu specimen and the holotype. The former (Fig. 4A) seems to be 
more tuberculated, the supra-orbital teeth more pronounced, with the distinct epibranchial cleft and tooth, narrower sternum and more distinctive colour pattern. As seen in $R$. pictus and $R$. pilipes new species, smaller specimens are usually more tuberculated than the larger ones. The narrower sternum of the Vanuatu specimen could be size related the sterna of females generally become broader as they increase in size. The Vanuatu specimen still has its colour markings on the carapace as opposed to the holotype. Most of the markings have already faded in the holotype. Thus, we cannot ascertain if the difference (see later in descriptions of colour) observed here is due to preservation or merely variation within the species. As for the other differences, with only two specimens on hand, we prefer to regard them as infra-specific variation for the moment. It is interesting to note that both the specimens were collected from very different depths (holotype from $73-84 \mathrm{~m}$; Vanuatu specimen from $550-571 \mathrm{~m}$ ). Whether the depth reading for either specimen is erroneous cannot be determined. Externally, the differences observed at present on the basis of only two female specimens do not warrant their recognition as a separate species.

Host records. - Although an arm of a crinoid was collected together with the holotype, identification was not possible. It at least confirms that $R$. xynon new species, is also a crinoid symbiont.

Distribution. - At the present moment, this species is only known from the Philippines and Vanuatu.

Colour. - Holotype: overall colour appearing purplish-brown including legs and chelipeds; a faint reddish-orange transverse stripe runs between the orbits reaching the anterolateral margins. Vanuatu specimen: overall appearing purplish-brown as well with additional reddish-orange markings; a transverse marking runs along the frontal and anterolateral margins; a concentric ring and a crescent shape marking present on the cardiac region; a whitish stripe runs longitudinally along the chelipeds; between the supra-orbital teeth there is a dark transverse stripe (see Fig. 10D).

\section{Morphology of the first zoea of Rhabdonotus pictus}

Fig. 9A-I

Description (Fig. 9). - Length of carapace (Fig. 9A) is ca. $0.7 \mathrm{~mm}$. Carapace with slightly hooked dorsal, short lateral and short rostral spine straight. Regions adjacent to lateral and dorsal spines heavily tuberculated, with scattered short setae, anterolateral margin lined with numerous sharp denticles. Eyes sessile. Abdomen (Fig. 9B) with five somites, six fused to telson. Dorsal surfaces of somite 2 with a pair of robust, lateral knobs, somites 3 to 5 each with a pair of distinct upward and backwardly directed spines. Somites 2-5 with a pair of posterolateral processes each, blunt on somite 2 , sharp on somites 3-5. Dorsal surfaces of somites 2-5 with varying number of short setae: 4 $6,4-6,4-5,4-6$ respectively; somites $2-5$ with two additional long hairs. Posterodorsal margins of somites $2-5$ with 8,10 , 10,8 minute denticles respectively. Pleopods absent on all somites. Telson (Fig. 9B) bifurcate, margins of furcae spinulose, each with 1 large lateral spine and 1 small dorsal spine. Inner margin of telson fork with 3 pairs of large setose spines.

Antennule (Fig. 9C) uniramous, unsegmented, cone-shaped, with 2 stout and long, 2 thin and short aesthetascs, 2 simple terminal setae.

Antennal exopod (Fig. 9D) approximately equal in length to spinous process, both sharply tapering. Spinous process with 2 rows of spinules on distal margin. Outer margin of exopod with 2 thick median spine; distal part with 2 rows of spinules.

Mandible (Fig. 9E) heavily chitinised, 

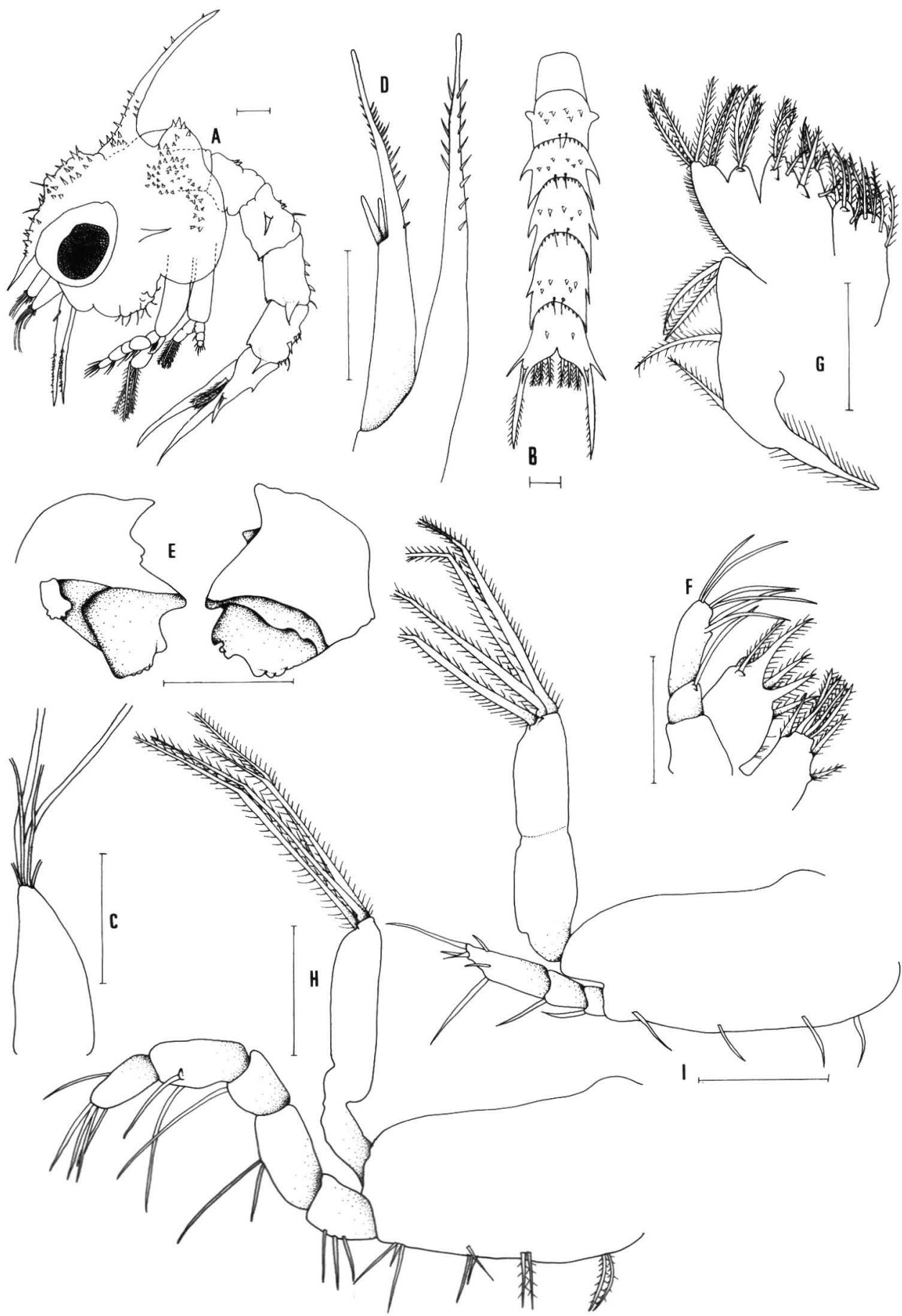

Fig. 9. Rhadonotus pictus A Milne Edwards, 1879, first zoea: A, lateral view; B, Abdomen (dorsal view); C, Antennule; D, Antenna; E, mandibles; F, Maxillule; G, Maxilla; H, First maxilliped; I, Second maxilliped. Scale bar $=0.1 \mathrm{~mm}$. 


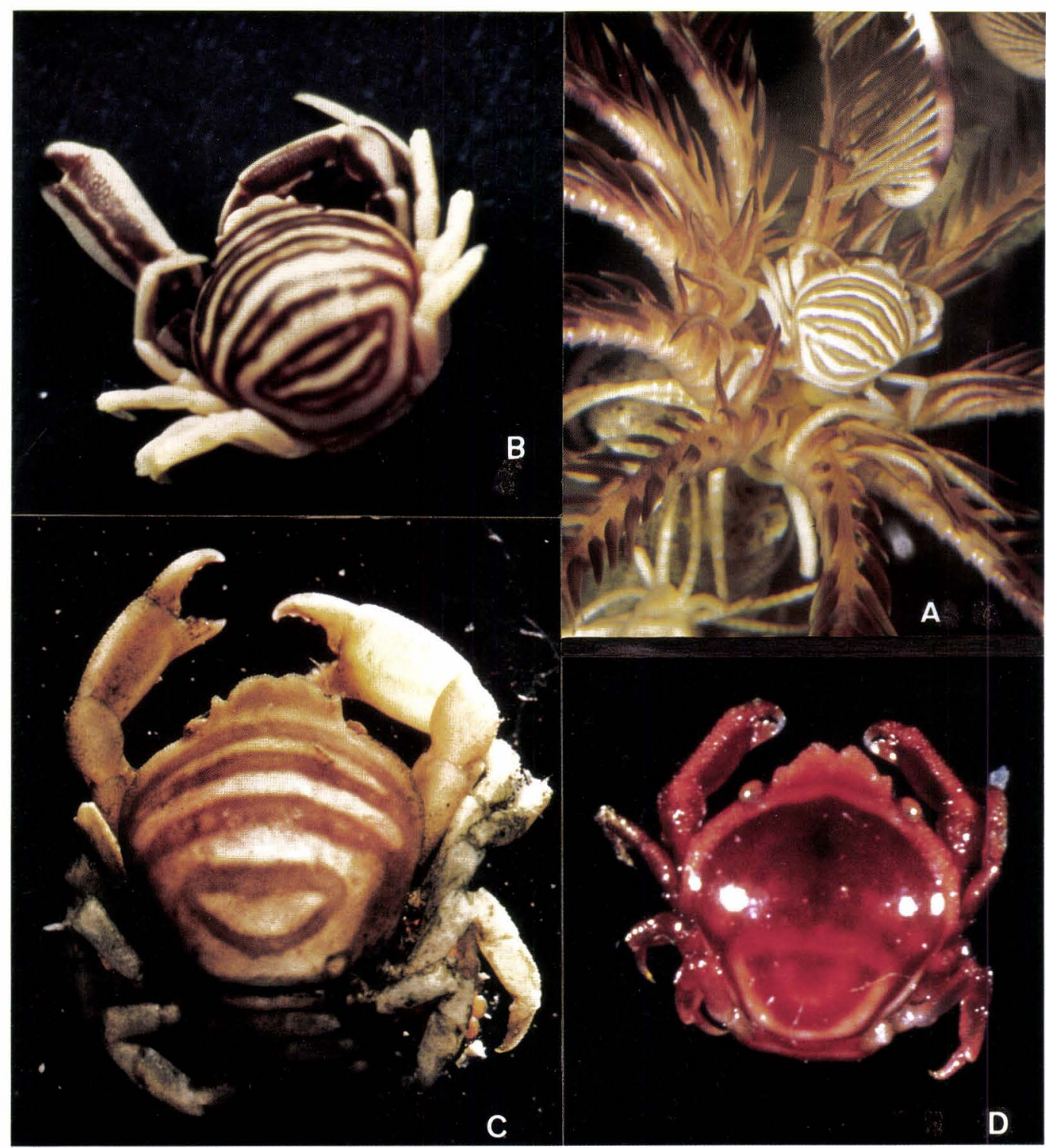

Fig. 10A-B. Rhadonotus pictus A Milne Edwards, 1879: A, female, cl. 5.3mm, cb 4.8mm, (ZRC 1995.224); B, female, cl 7.5mm, cb 7.2mm (ZRC 1989.2046) (Photo courtesy of K. Sagathevan); C, Rhabdonotus pilipes new species, one of the ovigerous paratypes, size not recorded (Photo courtesy of A. J. Bruce); D, Rhabdonotus xynon new species, female, cl $5.2 \mathrm{~mm}$, cb $4.9 \mathrm{~mm}$ (MNHN) (Photo courtesy of A. Crosnier).

both with inter-digitating incisor and molar processes, palp absent.

Coxal endite of maxillule (Fig. 9F) with 7 stout setae ( 4 terminal, 3 subterminal, stepped), basal endite with 2 serrated spines, 3 setae and 1 tubercle. Endopod 2- segmented, proximal segment with 1 long seta, distal segment with 2 subterminal and 4 terminal setae, stepped.

Coxal and basal endites of maxilla (Fig. 9G) bilobed, with 6, 5 setae on proximal lobes and 4, 4 setae on distal lobes re- 
Table 2. Differences between the first zoeal stages of Rhabdonotus pictus A. Milne Edwards, 1879, Harrovia longipes Lanchester, 1900 (fide Lim \& Ng, 1988) H. albolineata Adams \& White, 1849 (fide Chia et al., 1993), Echinoecus pentagonus Rathbun, 1894 (fide Van Dover et al., 1986) and Zebrida adamsi White, 1847 (fide Mori et al., 1991).

\begin{tabular}{|c|c|c|c|c|c|}
\hline & $\begin{array}{l}\text { Rhabdonotus } \\
\text { pictus }\end{array}$ & Harrovia longipes & $\begin{array}{l}\text { Harrovia } \\
\text { albolineata }\end{array}$ & $\begin{array}{l}\text { Echinoecus } \\
\text { pentagonus }\end{array}$ & Zebrida adamsi \\
\hline Carapace & $\begin{array}{l}\text { Regions around } \\
\text { lateral and dorsal } \\
\text { spines heavily } \\
\text { tuberculated, } \\
\text { with scattered } \\
\text { short setae, } \\
\text { anterolateral } \\
\text { margin lined with } \\
\text { numerous sharp } \\
\text { denticles }\end{array}$ & $\begin{array}{l}\text { Regions around } \\
\text { lateral and dorsal } \\
\text { spines finely } \\
\text { tuberculated, with } \\
\text { scattered setae }\end{array}$ & $\begin{array}{l}\text { Regions around } \\
\text { lateral and dorsal } \\
\text { spines finely } \\
\text { tuberculated, with } \\
\text { scattered setae }\end{array}$ & All regions smooth & All regions smooth \\
\hline Antennule & $\begin{array}{l}4 \text { aesthetascs, } 2 \\
\text { long, } 2 \text { short with } \\
2 \text { terminal setae }\end{array}$ & $\begin{array}{l}4 \text { aesthetascs, } 2 \\
\text { long, } 2 \text { short }\end{array}$ & $\begin{array}{l}4 \text { aesthetascs, } 2 \\
\text { long, } 2 \text { short }\end{array}$ & $\begin{array}{l}3 \text { aesthetascs, with } \\
2 \text { terminal setae }\end{array}$ & $\begin{array}{l}3 \text { aesthetascs, with } \\
1-3 \text { terminal setae }\end{array}$ \\
\hline $\begin{array}{l}\text { Maxillule: } \\
\text { Coxa }\end{array}$ & 7 setae & 7 setae & 8 setae & 7 setae & 7 setae \\
\hline $\begin{array}{l}\text { Maxilla: } \\
\text { Setal formula } \\
\text { (distal-proximal) of }\end{array}$ & & & & & \\
\hline $\begin{array}{l}\text { Basial } \\
\text { Coxa }\end{array}$ & $\begin{array}{l}4,5 \\
4,6\end{array}$ & $\begin{array}{l}4,4 \\
4,5\end{array}$ & $\begin{array}{l}4,5 \\
6,2\end{array}$ & $\begin{array}{l}4,5 \\
4,5\end{array}$ & $\begin{array}{l}4,5 \\
4,6\end{array}$ \\
\hline $\begin{array}{l}\text { Second maxilliped: } \\
\text { Setal formula } \\
\text { (proximal-distal) of } \\
\text { endopod }\end{array}$ & $1,1,6$ & $1,1,6$ & $1,1,5$ & $1,1,6$ & $1,1,6$ \\
\hline $\begin{array}{l}\text { Abdomen: } \\
\text { Posterolateral } \\
\text { process }\end{array}$ & Somites 3-5 sharp & Somites 3, 4 sharp & Somites 3-5 sharp & Somites 3-5 sharp & Somites 3-5 sharp \\
\hline
\end{tabular}

spectively. Endopod bilobed, with 3 setae on proximal lobe, setae on distal lobe stepped, in the arrangement of: 3,2 ; outer margin with fringe of fine hairs. Scaphognathite with 4 stout, plumose marginal setae; tip strongly tapered, plumose.

Coxa of first maxilliped (Fig. 9H) bare, basis with 10 setae $(2,2,3,3$, proximal to distal). Endopod five-segmented, setation from proximal to distal segment $3,2,1,2$, 5. Exopod constricted medially, appearing 2-segmented, with 4 stout, setose terminal natatory setae.

Coxa of second maxilliped (Fig. 9I) bare, basis with 4 setae $(1,1,1,1)$.
Endopod 3-segmented, setation from proximal to distal segment 1, 1, 6. Exopod constricted medially, with 4 stout, setose terminal setae. Third maxilliped absent.

Remarks. - The first zoeal stage of Rhabdonotus pictus is compared to those described for Harrovia longipes Lanchester, 1900 (fide Lim \& Ng, 1988), H. albolineata Adams \& White, 1849 (fide Chia et al., 1993), Echinoecus pentagonus (A. Milne Edwards, 1879) (fide Van Dover et al., 1986) and Zebrida adamsi White, 1847 (fide Mori et al., 1991). The differences (Table 1) observed are not significant at the species or genus level. The similarities observed are: 1) in the gen- 
eral shape of carapace, abdomen and antennule; 2) antenna's subequal spinous protopodal process and exopod; 3) setae arrangement on the endopod segment of maxillule in the groups of $4,2,1$ and on basial segment 5 ; 4) setae arrangement on the endopod of maxilla in the groups of 5,3 , and the scaphognathite bearing 4 plumose setae; 5) first maxilliped (see description above) is entirely the same for all species; and 6) setae arrangement on the basis of second maxilliped being 1,1 , 1,1 . The many similarities support the current contention that these genera belong to one monophyletic taxon (i.e. Eumedonidae).

\section{Acknowledgements}

Special thanks to the various curators for gracious loan of specimens and help in many ways: C. Fransen and Lipke Holthuis (RMNH), P. Clark (BMNH), K. Coombes (NTM), A. J. Bruce (NTM), D. Guinot and A. Crosnier (MNHN), P. Somsat (PMBC), P. Davie (QM) and C. M. Yang (ZRC). K. Sagathevan, A. J. Bruce and A. Crosnier kindly permitted us to use their colour slides of the various species. The authors would also like to express their thanks to R. Teo and T. M. Sin who identified the crinoids and for spotting the gravid female crab amongst the many crinoids collected during one of our field trips. Thanks are also due to W. L. Chiong, Alvin Wong, Desmond Wee, Kelvin Lim, Salam and Rahmat for their much appreciated help in the various field trips; P.Y. Aw for maintaining the marine aquarium, and L. M. Chou for loan of dredging equipment. The authors acknowledge the support of grant RP 900360 from the National University of Singapore to the second author. This is a contribution from the Ecology/Systematics Laboratory, no. 3/1995.

\section{Literature Cited}

Adams, A., \& White, A. 1848-1849. Crustacea, in Zoology of the Voyage of H.M.S. Samar- ang; Under the Command of Captain Sir Edward Belcher, C. B., F. R. A. S., F. G. S. during the Years 1843-1846 (A. Adams, editor), 1-66, pl. 1-13. Published in two parts: Part I (pp. 1-32, pls. 1-6) is dated on the cover 1848, Part II (pp. 33-66, i-vii, pls. 7-13) has the date 1849 on the front cover.

Balss, H., 1934. Sur quelques Décapodes brachyoures de Madagascar. Faunes des Colonies Françaises, 5: 501-528, pl. 1. , 1957. Decapoda, VIII: Systematik, in H. G. Bronns. Klassen und Ordnungen des Tierreichs, Band 5, Abteilung 1, 7(12): 1505-1672, fig. 1131-1199.

Chia, D. G. B., Ng, P. K. L., \& Van Den Spiegel, D., 1993. The identities of two crinoid symbionts, Harrovia albolineata Adams \& White, 1849 , and $H$. longipes Lanchester, 1900 (Decapoda, Brachyura, Eumedonidae). Crustaceana, 64(3): 259-280.

Crosnier, A., 1962. Crustacés Décapodes Portunidae. Faune de Madagascar, 16: 1154, pls. 1-13.

Dai, A., \& Yang, S., 1991. Crabs of China seas. $21+608$ pp., 74 pls. China Ocean Press, Beijing and Spinger-Verlag, Berlin.

- - Song, Y., \& Chen, G., 1986. Crabs of Chinese seas. pp. $17+642$, pls. $1-$ 74. China Ocean Press, Beijing, (In Chinese).

Dana, J. D., 1853. Crustacea. In United States Exploring Expedition during the years $1839,1840,1841,1842$, under the command of Charles Wilkes, U.S.N., 13, pt. 2: 686-1618.

Guérin-Méneville, F. E., 1829-1844. Iconographie du regne animal de G. Cuvier, ou représentation d'après nature de l'une des espèces les plus remarquables, et souvent non figurées, de chaque genre d'animaux, avec un text descriptif mis au courant de la science: Ouvrage pouvant servir d'atlas à tous les traités de zoologie. Pls. 450 in 45 livraisons. Crustacea: 36 pls., 48 pp. Paris. Griffiths, F. B., Flemminger, A., Kimor, B., \& Vanuccu, M., 1976. Shipboard and curating methods. In: H. F. Steedman, (Ed.), Zooplankton fixation and preservation, Paris: UNESCO Press, pp. 17-33.

Johnson, D. S., 1962. Commensalism and semi-parasitism amongst Decapod Crustacea in Singapore waters. In: Proceedings of the First Regional Symposium on Scientific Knowledge of Tropical Parasites. University of Singapore, pp. 282-288.

-1967 . On some commensal decapod crustaceans from Singapore. Journal of Zoological Society of London, 153: 499-526. 
Lanchester, W. F., 1 ? Crustacea made at ? Pt. I. Crustacea Br the Zoological Sr 719-770, pls. 44-

Leene, J. E., 1938. Br The Decapoda Bra. pedition, VII. Sibo 1-156.

Lim, G. S. Y., \& Ng, zoeal stage of $\mathrm{Ha}$. and White, 1848 Pilumnidae), wit systematics. Jor 22(1): 217-223.

Lundoer, S., 197 . Brachyura ir PMBC, Tho Phuket Mari. 11.

de Man, J. G., 1888. Bericht über die von Herrn Dr. J. Brock im indischen Archipel gesammelten Decpoden und Stomatopoden. Archi für Naturgeschichte, 53 (I Band, 3 Heft): 289-600, Taf. XI-XXIIa.

Milne Edwards, A., 1879. Description de quelque Crustacés nouveaux. Bulletin de la Société Philomatique de Paris, ser. 7 (3): 103-110.

Milne Edwards, H., 1834. Histoire naturelle des Crustacés, comprenant l'anatomie, la physiologie et la classificaiton des ces animaux, Volume 1. xxxv + $468 \mathrm{pp}$., Librairie Encyclopédique de Roret, Paris.

Mori, A., Yanagisawa, Y., Fukuda, Y., \& Ng, P.K.L., 1991. Complete larval development of Zebrida adamsii White, 1847 (Decapoda: Brachyura), reared in the laboratory. Journal of Crustacean Biology, 11(2): 292-304.

Naiyanetr, P., 1980. Crustacean fauna of Thailand (Decapoda and Stomatopoda). Chulalongkorn University, Bangkok, Mimeographed, pp. 1-73.

Nobili, G., 1901. Decapodi e stomatopodi eritrei del Museo Zoologico dell'Università di Napoli. Annuario del Museo Zoologico della R, Università di Napoli, nuova serie, 1930: 1-20.

- _ 1906. Crustacés Décapodes et Stomatopodes: Mission J. Bonnier et Ch. Pérez (Glofe Persique 1901). Bulletin Scientifique de la France et de la Belgique, 40: 13-159, pls. 2-7.

Rathbun, M.J., 1894. Notes on the crabs of the Family Inachidae in the United States National Museum. Proceedings of the United States National Museum, 17: 43-75, pl. 1. Sankarankutty, C., 1966. On Decapoda
Brachyura from the Gulf of Manaar and Palk Bay. Proceedings of the Symposium on Crustacea held at Ernakulam from January 12-15, 1965, 1, Marine Biological Association of India, Mandapam Camp, pp. 347-362, pls. 1-2.

Serène, R., 1968. The Brachyura of the IndoWest Pacific Region. In Prodromus for a checklist of the non-planctonic marine fauna of South East Asia. Singapore National Academy of Science, Special Publication number 1, 1-120.

-, \& Romimohtarto, K., 1963. On some species of Eumedonidae from Indo-Malayan region. Marine Research in Indonesia [Penelitian Laut di Indonesia], number 6: 1-14, pls. 1-2.

Shen, C. J., Dai , A. Y., \& H. L. Chen, 1982. New and rare species of Parthenopidae (Crustacea: Brachyura) from China Seas. Acta Zootaxonomica Sinica, 7(2): 139-149, pls. 1, 2.

Stephenson, W., 1962. Evolution and ecology of portunid crabs, with special (sic) reference to Australian species. In: G. W. Leeper (ed.), The evolution of living organisms. A symposium of the Royal Soeciety of Victoria held in Melbourne, Decmeber 1959, pp. 311-327, Melbourne University Press, Melbourne.

,- 1972 . An annotated checklist and key to the Indo-West- Pacific swimming crabs (Crustacea: Decapoda: Portunidae). Bulletin of the Royal Society of New Zealand, No. 10: 1-64.

_ \& Campbell, B., 1960. The Australian portunids (Crustacea: Portunudae). IV. Remaining genera. Australian Journal of Marine and Freshwater Research, 11(1): 73122 , pls. 1-6.

Stevcic, Z., 1991. Note on some rare and aberrant Autralian crabs. Beagle, Records Northern Territory Musuem of Arts and Science, 8(1): 121-133.

-, Castro, P., \& Gore, R. H., 1988. Re-establishment of the family Eumedonidae Dana, 1853 (Crustacea: Brachyura). Journal of Natural History, 22: 1301-1324.

Van Dover, C. L., Gore, R. H., \& Castro, P., 1896. Echinoecus pentagonus (A. Milne Edwrads, 1879): larval development and systematic position (Crustacea Brachyura: Xanthoidea nec Parthenopoidea). Journal of Crustacean Biology, 6(4): 757-776.

Walker, A. 0., 1887. Notes on a collection of Crustacea from Singapore. Journal of the Linnean Society, Zoology, 20: 107-117, pls. 6-9. 
Ward, M., 1934. Notes on a collection of crabs from Christmas Isalnd, Indian Ocean. Bulletin of the Raffles Museum (Singapore), No. 9: 5-28, pls. 1-3.

White, A., 1847. Descriptions of new or littleknown Crustacea in the collection at the British Museum. Proceedings of the Zoological Sciety of London, part 15: 118-126.
Wu, P. (ed.), 1983. Latin - Chinese marine organism names. 822 pp., Ocean Press, Beijing. (In Chinese)

Department of Zoology, National University of Singapore, Lower Kent Ridge Road, Singapore 0511. 